\title{
HISTORY OF THE EMPLOYMENT OF WOMEN IN THE AMERICAN COTTON MILLS. PART III
}

\author{
EARLY MILL OPERATIVES (continued). THE PERIOD OF \\ TRANSITION
}

Conditions of work in the cotton mills of the first half of the nineteenth century were far from ideal. The mills of this period were very badly constructed from the point of view of sanitation, or safety, or comfort. They were for the most part narrow and extremely high buildings-sometimes with seven stories; they were low-studded, heated by stoves, badly ventilated, and badly lighted; weavers depended on the old "petticoat lamps," as they were called, which were fastened to the loom and filled with whale-oil, to be ready when the light failed. Moreover, little attention was given to apparatus for removing the fine dust which is so unhealthful in cotton mills or to any artificial means of ventilation. ${ }^{28}$ Dr. Josiah Curtis, in his very able study of hygienic conditions in Lowell in I849, said quite emphatically that bad ventilation in the mills was "the most prolific source of deteriorated health in the adjuncts of factory labor among us and in our neighboring factory towns.", 29 The hours were notoriously long, generally from five in the morning till seven at night. The girls went in for two hours' work before breakfast and returned to the mills again in the evening after supper, except during very brief periods in the year. The meager half-hour allowed for breakfast at seven o'clock and for dinner at noon was much complained of by the operatives and by physicians in their behalf. While fourteen hours was sometimes the period of work, twelve and three-quarters was probably the average length of the work-

${ }^{28}$ Edward Atkinson writes very forcibly as to most of these points in the Tenth Census, Vol. II, p. 953.

${ }^{20}$ Dr. Curtis says further, with regard to this subject: "In winter, moreover, for four months, when the windows are closed and generally double, each room has fifty solar lamps burning morning and evening, which assist not only in impairing the confined air, but also in raising the temperature frequently to $90^{\circ}$ F. before closing work at night." 
ing day before May I, I847. "Overtime," too, was not unknown, and the lamps were sometimes kept burning until nine or ten o'clock, but it was claimed as a justification that "overtime was always voluntary." 30

In some mills the working-day varied, with the season of the year, from twelve hours in the winter to fourteen in the summer. It is an evidence of the temporary character of their employment that some of the girls who were on piece-work rates preferred the longer hours - their object being to gain a certain fixed sum of money and then leave the mills, and the higher earnings that were the result of the longer hours meant an earlier release. One skilled and intelligent girl, in answering charges that were made in a political speech about the abuses of the mills, said :

We never work more than twelve and a half hours a day; the majority would not be willing to work less, if their earnings were less, as they only intend working a few years, and they wish to make all they can while here. ${ }^{31}$

Conditions in the corporation boarding-houses varied much with the character of the women in charge, but in any case the bedrooms were very crowded and uncomfortable and little, if any,

${ }^{30}$ Miles, Lowell as It Was and as It Is (1847), p. I08. He adds, "The young woman, who is able, is generally willing to engage in it, as she draws the pay, to the extent of the extra work, of two girls, while she incurs the expense of the board of but one." For further discussion as to hours in Lowell, see Josiah Curtis, Brief Remarks on the Hygiene of Massachusetts, etc. (1849), p. 27, note; Miles, op. cit., p. Ior; Robinson, Loom and Spindle, p. 31. In Fall River the hours must have been even longer. Hannah Borden's day seems to have been as follows: she rose at 4 , took her breakfast with her to the mills, and at 5 had her two looms under way. From $7: 30$ to $8: 30$ she had an hour for breakfast, at noon half an hour, and the looms did not stop again till 7:30 P. M. It was 8 o'clock before the girls reached their homes, and they were said to be so tired that it was not unusual for one to fall asleep at the supper table. See Wixon, op. cit.

${ }^{31}$ Quoted in Robinson, op. cit., p. 94, and see the New England Offering, Vol. I, pp. 48, 79: "One overseer said the girls would rather work more hours than less. When Mr. G. gave them three-quarters of an hour for breakfast, they shut the gates to keep the girls out; and .... in twenty minutes from the time they came out, one hundred were there on that bridge waiting-and not very patiently either-for the gates to open." Another extract from the same magazine is very significant: "Every overseer and girl in the New England mills knows perfectly well, or may know, that the majority if not the whole body of the weavers and spinners prefer to work as long as they can.... They enter the factories to make money."--Ibid., July, I848, cover. 
better ventilated than the mills. The comment of Dr. Curtis was that the condition of the sleeping-apartments would not be endured so passively if the occupants had not first become habituated to such unwholesome air in the mills. Often six or eight girls occupied a single bedchamber, and the descriptions in the Operatives' Magazine ${ }^{32}$ of rooms so "absolutely choked with beds, trunks, bandboxes, clothes, umbrellas, and people, that one finds it difficult to stir, even to breathe freely," were probably not exaggerated. This was particularly trying when the girls were not congenial, and stories in the Offering indicate that this was frequently enough the case. But it was easier to bear patiently with unsatisfactory conditions, when one was to have only a very temporary connection with them, than to take either the time or trouble to remedy them. Complaints of the "long hours, the close workrooms, the crowded chamber" ${ }^{33}$ were not wanting, but it was following the line of least resistance to treat these as the inevitable discomforts of an occupation which was to be followed for a very short time at most. Thus Miss Larcom, writing many years later, says emphatically, "Certainly we mill girls did not regard our own lot as an easy one, but we had accepted its fatigues and discomforts as unavoidable, and could forget them in struggling forward to what was before us."34 They even took pride in the fact that they were above complaining about the

${ }^{32}$ Vol. II, p. Ioo, and see Curtis, op. cit., p. 33, and Scoresby, American Factories, etc., p. 57. See also an interesting report by another physician, Dr. Kimball, in which attention is called to the badly ventilated mills and boardinghouses. With regard to the latter he says, "The ventilation of our corporation boarding-houses is very imperfect, particularly as regards the sleeping apartments ... ; in at least some of the boarding-houses there is a manifest disregard of cleanliness, .... in some of the tenements more occupants than their rooms will well accommodate."-Report of the Lowell Hospital from I840-I849. Made to the Trustees, June I2, I849, by Gilman Kimball, M.D., (Lowell, I849). p. I4. For further statement as to unwholesome conditions in sleeping-rooms of corporation boarding-houses, see Bill of Mortality of City of Lowell for I854, p. 22.

${ }^{33}$ See, e.g., New England Offering, Vol. I, p. 48.

${ }^{34}$ Larcom, Atlantic Monthly, Vol. XLVIII, p. 6ro. She says further, "The mistaken impression went abroad that a paradise of work had at last been found. Romantic young women came from a distance with rose-colored pictures in their minds of labor turned to pastime, which were doomed to be sadly blurred by disappointment." 
physical discomforts of their work. The editor of the Offering says of the contributors,

they have done honor to their heads and hearts. They have shown that their first and absorbing thought was not for an advance of wages or a reduction of labor hours. They have given the impression that they were contented even with their humble lot.... They have striven for improvement of head and heart before that of situation. They have attended more to self-reformation than to the reformation of society.

When it was charged that the editorial policy of the magazine was to present only the bright side of factory life and therefore to convey an essentially false impression, the answer of the editor was, "Happy indeed are we, if our eyes can turn involuntarily to the sunny side of the objects which arrest our gaze."35 All of this is, of course, an illustration of the familiar fact that a labor movement is born only when a definite wage-earning class is created which is concerned with the permanent improvement in the condition of that class, and is willing to make sacrifices in its behalf. To quote Miss Larcom again $:^{\mathbf{3 6}}$

This feeling, that they were at work in the mills for a little while, only to accomplish some special purpose, gave them contentment without any sacrifice of independence. Rumors of intended reductions of wages would often bring rumors of intended "strikes," but the quiet, steady-going ones formed a large majority who gave no aid or sympathy to violent measures, and the murmur of disaffection soon died away. What reason had these young girls for nursing a sense of injuries, with all New England beckoning them back to their native hills, to the homes that were missing them, and would overflow with rejoicing when the absent sister or daughter should see for herself that it was no longer worth while for her to stay away?

Moreover, these girls were compensated in some measure by the sense of being pioneers and successful pioneers. They had a clear vision of the future and saw that pecuniary independence

${ }^{35}$ See the closing editorial, New England Offering, Vol. I, p. 376, "We have been accused by those who seem to wish us no ill, ... . of unfaithfulness to ourselves as exponents of the general character and state of feeling among the female population of this city. They say the Offering .... does not expose all the evils and miseries and mortifications attendant upon a factory life. It speaks, they say, on only one side of the question; and they compare us to poor caged birds, singing of the flowers which surround our prison bars, and apparently unconscious that those bars exist."

${ }^{36}$ Larcom, op. cit., pp. 609-10. 
with the opening of a large and remunerative field of employment for women held for them the promise of a new world. They had a conscious pride, too, in upholding the dignity of labor, in demonstrating that in a republic "work with the hands is no disgrace." In the words of one of these pioneers, they were

clearing away a few weeds from the overgrown track of independent labor for other women. They practically said by numbering themselves among factory girls that in our country no real odium could be attached to any honest toil that any self-respecting woman might undertake.

The poet Whittier, who saw many evils connected with the early cotton industry, found compensation for the hardships suffered in the mills in the fact that there, more than in any other mechanical employment, women's labor was placed essentially upon an equality with men's. Writing from Lowell he said:

Here, at least, one of the many social disabilities under which woman, as a distinct individual unconnected with the other sex, had labored in all times is removed; the work of her hands is adequately rewarded; and she goes to her daily task with the consciousness that she is not spending her strength for naught. ${ }^{37}$

On the whole, then, it seems fair to say that conditions in early Lowell,

That wonderful city of spindles and looms

And thousands of factory folk,

as it appeared to so many girls at that time, were far from being as idyllic as those who are prone to idealize the past would have us believe. Long hours, unsanitary mills, crowded boardinghouses, compulsorily supported corporation churches, all of these things are forgotten, and the young factory town seems to us, as it seemed to Dickens and other early visitors, sufficiently justified because of the remarkable intelligence and refinement of its operatives. But their presence there was not symptomatic of ideal conditions in the mills, but rather of the lack of alternative employments for women of education or superior abilities at that time. Harriet Martineau, with her keen powers of observation, saw the situation truly when she wrote:

${ }^{37}$ See the description of Lowell, "The City of a Day," in Whittier's Prose Works, Vol. I, pp. 35 I-84. 
Twice the wages and half the toil would not have made the girls I saw happy and healthy, without that cultivation of mind which afforded them perpetual support, entertainment, and motive for activity. Their minds were so open to fresh ideas as to be drawn off from thoughts of themselves and their own concerns.

It should, perhaps, be asked at this point: How far were the girls of the Improvement Circle typical of the whole body of Lowell operatives? and how far was Lowell a typical example of the mill towns of the period? The first question is raised by the editor of the Lowell Offering herself. Have these factory "blues" (as they loved to call themselves) represented the factory operatives as a class? she asks; and replies:

In truth it is such a promiscuous class that it would be impossible for any one magazine or paper, . . . to represent them. It is generally conceded that they represent the more intelligent portion of them. ${ }^{38}$

But certainly Emily and Lucy Larcom, Margaret Foley, and Harriet Farley would have been exceptional in any group of women; and Miss Larcom, writing later of her early associates, says in her quiet, truthful way that hundreds of the thousands of girls at work then did not care at all either for books or study, but worked at Lowell just as they would have worked earlier "at the family sewing or at any household toil at home."

It has already been pointed out that conditions in the mill towns in southern New England, particularly in Rhode Island, were essentially different from those which prevailed in towns of the Lowell type. The "family system" made the corporation boarding-house unnecessary and the operatives were clearly drawn from a lower social stratum. ${ }^{39}$ That Lowell itself was an ordinary mill town, except for its size, and was much like a large number of other towns in the district which followed more or less

${ }^{38}$ Lowell Offering (editorial), Vol. V, p. 263.

${ }^{30}$ Many points of contrast between Lowell and these mill towns of the south might be found. For example, Seth Luther, in his rather inflammatory Address to the Workingmen of New England (Philadelphia, 1836), publishes an account of the corporal punishment of one of the women operatives in a Rhode Island mill by an overseer in a spinning-room-an incident which resulted in the prosecution and conviction of the man in the court of common pleas. Such an incident could not possibly have happened in Lowell. 
the same system, is probably true. Waltham was the prototype of Lowell and cherished as high a reputation for morality. ${ }^{40}$ The "Rumford Institute" of Waltham, a system of popular lectures founded in the interest of the factory operatives and much patronized by them, was the first lyceum in the country. And not only Waltham but Lancaster, Chicopee, Manchester in New Hampshire, and Newmarket, Exeter, Portsmouth, and Dover in the same state, and many other mill towns seem to have cared for their operatives in carefully supervised corporation boarding-houses like those of Lowell. The rules of the Lancaster boarding-house, which have been preserved, are not unlike those prescribed by Kirk Boott for Lowell. ${ }^{41}$ The Lowell Offering opened its pages to operatives from other factory villages, and contributions were printed that came from various towns not only in Massachusetts but New Hampshire, Maine, and even Rhode Island $;^{4}$ but in the south of New England the mill towns were far inferior to those of the Lowell and Waltham type.

But since the exceptional fame of early Lowell and the towns like it was due to their having a unique body of operatives and not to any superiority of their mills or boarding-houses, so the withdrawal of the girls who represented the best of the older New England farm life meant the close of a remarkable period in the history of the American cotton manufacture. By the year I850 the old order was quite obviously passing away. The days when printed regulations were necessary to prevent the bringing of books into the mills, when young girls pasted their

${ }^{40}$ See the section in Miles, op. cit., pp. $2 \mathrm{I}-24$ on "Waltham, the Parent of Lowell ;" and see Boston Newsletter and City Record, August 19, 1826, p. 83.

${ }^{41}$ See the note at the close of the article for a reprint of these rules.

${ }^{42}$ It is an interesting instance of "community of interest," that the "Lowell Circulating Library," which was so lavishly patronized by the mill girls, seems to have been transplanted almost in its entirety with its two thousand volumes from Dover, one of the well-known New Hampshire mill towns. (See the note on the title-page of the old catalogue which is preserved in the Boston Public Library.) Attention might also be called to the fact that bathing-rooms had been established by corporations in Manchester, New Hampshire, before they were instituted in Lowell. There are in fact many little points which seem to show that the other towns of the same type were not unlike Lowell except that they were smaller. 
spinning frames with verses to train their memories to work with their hands, when mathematical problems were pinned up in the "dressing" room, these were the days which Lowell was soon to know no more. The new body of operatives were not like these daughters of the Puritans, who debated earnestly with their consciences as to whether it was "right to be at work upon material so entirely the product of slave labor as cotton," and cheerfully payed out of their own hard earnings not only their pew rents but liberal subscriptions to missions and charities of many sorts. ${ }^{43}$ The commercial crisis of $1848-49$ may be said to mark a turning-point in the history of social conditions in Lowell. Changes were already in progress before that event, but they came more rapidly in the wake of an industrial depression.

The women who came over in the earliest wave of Irish immigration did not compete directly with the girls in the betterpaid factory occupations. Domestic service was the first great field of employment for immigrant women though some of them found places at very low-grade work in the mills. Lucy Larcom tells of an Irish woman who was employed as a waste-picker on the corporation where she worked as a child, and who was regarded as a great curiosity by the other operatives.

But the moving of the New England girls of the old stock out of the mills into higher-grade occupations, and the filling of the vacant posts by Irish women, had become common enough in the latter half of the forties. As early as I 845 several of Lucy Larcom's friends had emigrated to the West as teachers or missionaries, ${ }^{44}$ and the New England Offering was obliged to call for support not only from "those who are," but from "those who have been factory operatives;" references to the mill girls who had given up factory work permanently and become teachers are frequent $;^{45}$ and letters were published in the Offering from

${ }^{43}$ See Larcom, Atlantic Monthly, pp. 600, 607, and also the New England Girlhood, p. 256. In the latter she says, "The needs of the West were constantly kept before us in our churches. We were asked for contributions for home missions, which were willingly given. . . . . There was something almost pathetic in the readiness with which this was done by young girls who were longing to fit themselves for teachers but had not the means."

${ }^{44}$ New England Girlhood, p. 257.

${ }^{45}$ See, for example, Nerw England Offering, Vol. I, p. 94. 
former mill-girls who had found positions in Missouri, Arkansas and Illinois.

The crisis of $1848-49$, with its accompanying reduction of wages, gave a quickening impulse to the changing order. High wages had been the chief attraction of the mills, and without this, the most intelligent of the women operatives, who now saw other opportunities for work opening to them, found nothing to keep them in Lowell. ${ }^{46}$ As early as I85I, an English traveler noted that the great demand for operatives had "gradually introduced black sheep into the workshops, and disreputable neighbors in the crowded streets :" 47 Irish women who would have entered domestic service during the first decade after Irish immigration began, gradually drifted into the mills during the forties, and in the early fifties ( $1853-54$ ) when James Robertson visited Lowell he found that half of the operatives were Irish and that the former high tone of the place had been lowered. ${ }^{48}$ Miss Farley in the pages of the New England Offering laments this exodus of her New England sisters and forecasts the permanence of the change in the body of operatives. She saw the "great West open for our girls away there, with all this clamor for teachers, missionaries, and wives," and she felt that with only "the Irish

${ }^{46}$ An article in the Offering, December, 1848, on "The Rights and Duties of Mill Girls," makes the following reference to their departure: "New England cotton mills are, and for the last six months have been, running at a positive loss, and therefore lowering speed and lessening wages;.... the girls are leaving the mills by the thousand here and elsewhere."

${ }^{47}$ J. F. W. Johnston, Notes on North America (London, 1851), p. 423. The late James E. McNeill tells of an interesting method of obtaining hands in some districts when the scarcity of operatives was felt. A long, low black wagon was employed in making regular trips to the northern part of Massachusetts and around in Vermont and New Hampshire. The man having this team in charge was paid a dollar a head for all the girls he could secure, a larger amount being given according as the distance he traveled was greater. It was charged that he misrepresented facts to the girls thus engaged, telling them the work was very neat, wages high, and that they could dress in silks and spend half the time in reading! See McNeill, The Labor Movement, p. Io6.

${ }^{48}$ In consequence, he added, "the reputation of the employment has suffered in the estimation of those whose daughters, under more favorable circumstances, would have become workers in the place." 
and low-class New England girls" remaining, a great and deplorable change of conditions in L.owell would result. ${ }^{49}$

Later in the year the evidences of the substitution of lowgrade Irish help had become more marked, and the Offering complained that so many of the best operatives had either gone West or settled permanently into some other kind of work, that now "the good old times will not return even if the good old wages are again held out as an inducement." 50 Other signs of change appeared. An overseer noted that there was an increasing number of illiterate operatives who "made their mark" because they could not sign their own names. Shopkeepers and boarding-house managers declared that they found themselves dealing with a new mill population.

The reduction of wages was not, of course, wholly responsible for this "downward tendency," as it was called in Lowell. It was inevitable that the opening of occupations for educated women should mean their withdrawal from mechanical employments of a lower grade. The reduction of wages hastened but did not cause the movement. The fact that there were increasing opportunities for women as teachers was also in part responsible for the change. From 1838 to 1847 the increase in the number of women teaching in Massachusetts was 1,647, while during the same time the number of men in the profession increased but 67 . In 1850 the number of women teachers in the state was more than twice the number of men. Moreover, there had been three normal schools established which made it possible for a woman to fit herself for teaching. By the close of the first half of the century the cotton mill had ceased to be the preparatory school for the women teachers of Massachusetts, and during the

${ }^{49}$ Wages, she thought, would come down as a result of the comparative unprofitableness of the new employees, and "they will submit, since they have little energy, few aspirations to be ministered unto by their gains, and having poor homes, or little of the home sentiment, they will stay, and wages may be reduced again and again."-Ibid., p. 156.

${ }^{50}$ Article by Miss Farley on "The Present Crisis," New England Offering, pp. I67, I68. Miss Farley adds in her editorial that other causes than the reduction of wages have brought about the "downward tendency." Among these, less watchfulness over the morals of the operatives by superintendents and boardinghouse keepers and less care as to the morals of the male subordinates in the mills. She felt that there was, in general, much immorality in the city. 
ten years preceding the Civil War, the proportion of educated women among the operatives constantly decreased.

In the following decade, I860-70, the effect of the war was to hasten the withdrawal of educated women from the mills. In many directions there was an increased demand for the work of women of this class. They were wanted as nurses and for teaching posts left vacant by men who had gone to the front, and for clerical positions of many kinds. Moreover, the prosperity of the farming population, particularly in New England, diminished the necessity for the employment of the daughters. Immediately after the war, the lure of the West, of the vast riches of its unexploited mines and prairies, was felt; and energetic and ambitious women pushed out to earn the high wages that were being offered to teachers.

This outward movement of New England women into new professions and into new sections of the country was further stimulated by the prolonged depression in the cotton industry which was caused by the war. The Merrimack, the oldest and largest of the great corporations, dismissed its operatives and discontinued its purchases of cotton. Many other companies followed the same policy and allowed their mills to stand idle while they waited for peace. Experiments were made in some cases with other branches of manufacture. In Lowell, the Suffolk and Tremont corporations attempted, unsuccessfully, to manufacture cassimeres, the Lawrence turned to the hosiery industry, the Hamilton threw out part of its cotton machinery and prepared for the manufacture of woolen goods. Thousands of cotton operatives were dismissed and the position of those who remained was less desirable since there was not a sufficient increase in wages to correspond with the sharp upward movement of prices. As a result, when the war ceased, the most capable and intelligent of the old body of operatives had entered other employments, and, with the reopening of the mills, such difficulty was found in obtaining competent women employees that lowergrade immigrant labor was resorted to. ${ }^{51}$

${ }^{51}$ The following comments of a local historian written soon after the war are of interest: “.... nine of the great corporations of Lowell, under a mistaken belief that they could not run their mills to a profit during the war, 
At a meeting of the New England Cotton Manufacturers' Association, in I869, complaint was made of the scarcity of skilled labor although "ordinary help" seemed to be abundant. ${ }^{2}$ Many manufacturers testified to a decrease in the efficiency of labor after the war. It was estimated by Commissioner David A. Wells ${ }^{53}$ in the summer of 1866 , that the produce of the cotton mills of New England was variously reduced from 5 to 25 per cent., because of the impossibility of finding women operatives; "an unusual scarcity of female operatives-particularly-in the manufacturing districts of New England-has not been remedied by a large advance in wages." Wages of course had risen during the war, but cost of living had increased so disproportionately that real wages were much less, and the attraction of the mills was correspondingly decreased. Not only the native born but the immigrant Irish operatives were seeking higher-grade employments and a new wave of immigration was beginning to fill their places with less skilled and less efficient hands from the French Canadian provinces. In 1872, when Mr. Harris Gastrell made his report ${ }^{54}$ to the English government he found the labor chiefly Irish, but the French Canadian operatives conspicuous enough to be mentioned. The report of the Massachusetts Bureau of Labor in I870 speaks of the Irish element in the mills as "falling off," and of a new class, "the French Canadians who are coming into New England and New York by thousands of

unanimously, in cold blood, dismissed ten thousand operatives penniless into the streets..... When these companies resumed operations, their former skilled operatives were dispersed, and could no more be recalled than the ten lost tribes of Israel. Their places were poorly filled by the less skilled operatives whom the companies now had to employ"-Cowley, History of Lowell, rev. ed. (Boston and Lowell, I868), pp. 6o, 61. For another criticism of the mills for shutting down, see J. C. Ayer, Some of the Usages and Abuses in the Management of Our Manufacturing Corporations (Lowell, I863), p. 22.

${ }^{52}$ Transactions of the Association ( 1869 ), p. 5. See also testimony in the "Weeks Report," Tenth Census, Vol. XX, p. 346, 36r.

${ }^{53}$ Report of the special commissioner of revenue, Sen. Doc., 2d Sess., 39th Congress, Vol. I, pp. 2 I ff.

${ }^{54}$ In Reports on the Condition of the Industrial Classes in Foreign Countries and the Purchase Power of Money, etc., 3 parts, I870-72. 
familics and making permanent settlement among us." "55 Some overseers, it appeared, preferred "foreigners," who, instead of coming from country homes, lived in the town as the Irish did, and could be relied on to work in the mills the year round "without bothering about vacations." „56 In I873 attention was called to the fact that there was clearly being created "what the founders of Lowell never looked for-a permanent body of factory employees, composed in part of American stock but more largely of Irish and French Canadian elements." 57 Complaint was made of more and more crowded boarding-houses; twelve persons were reported by a woman operative to be sleeping in one room in the boarding-house where she lived and the room was uncomfortable in other respects. ${ }^{58}$ But with the decrease in the number of operatives who came from the country to reside temporarily in Lowell and a corresponding increase in the number of those who resided permanently, in many cases with their families, the need for corporation boarding-houses largely disappeared. Many of them have now been entirely given up and turned into storehouses. The immigrant woman ${ }^{59}$ has no interest in operatives' magazines, improvement circles or lending libraries. She has no theories about making labor or laborers alike self-respecting and respected. And it must not be forgotten that the operatives have changed not only in nationality but in age. The fact that there are more of the old and the very young in the mills, more married women and more children, is in itself symptomatic of the existence of an inferior factory population. Moreover, as it has been pointed out $^{60}$ the men are now outnumbering the women.

${ }^{55}$ First Annual Report, p. 91.

${ }^{56}$ Ibid., p. II9. $\quad{ }^{57}$ Ibid., report for 1873, p. 28 I. $\quad{ }^{58} I$ Ibid., p. I2I.

${ }^{59}$ The following percentages computed from statistics in the Twelfth Census (I900), Occupations, Table 43 show the percentage of foreign born, and of those "foreign born or of foreign parentage," among cotton-mill operatives.

\begin{tabular}{|c|c|c|c|c|c|}
\hline & Massachusetts & Lowell & Fall River & Lawrence & New Bedford \\
\hline $\begin{array}{c}\text { Percentage of foreign } \\
\text { born operatives }\end{array}\left\{\begin{array}{l}\text { Men..... } \\
\text { Women }\end{array}\right.$ & $\begin{array}{l}72 \\
68\end{array}$ & $\begin{array}{l}73 \\
68\end{array}$ & $\begin{array}{l}7 \mathrm{I} \\
74\end{array}$ & $\begin{array}{l}70 \\
62\end{array}$ & $\begin{array}{l}78 \\
73\end{array}$ \\
\hline $\begin{array}{l}\text { Percentage of opera- } \\
\text { tives, "foreign born } \\
\text { or of foreign parent- } \\
\text { age" }\end{array}$ & $\begin{array}{l}95 \\
95\end{array}$ & $\begin{array}{l}9 \mathrm{I} \\
92\end{array}$ & $\begin{array}{l}96 \\
97\end{array}$ & $\begin{array}{l}93 \\
94\end{array}$ & $\begin{array}{l}96 \\
96\end{array}$ \\
\hline
\end{tabular}

${ }^{60}$ See Part I, Statistics of Employment, in November, 1908, this Journal. 
With the formation of a fairly permanent body of factory operatives other changes have come. Attempts have been made gradually to bring about improvements in working conditions which did not seem worth the struggle to the early operatives who were there only for a brief term of service. Thus the organized movement for a shorter working day which the superior transient factory population refused to undertake, has long been in progress and has achieved some notable results. Tradeunionism has been slowly taking root as a growing class consciousness has recognized the need of fostering ${ }^{61}$ a permanent organization to protect class interests as such.

The community, too, has awakened to a greater sense of its responsibility for unhealthful industrial and social conditions, as it has come face to face with the fact that large numbers of people will always live and work in them. The law has compelled mill owners to improve ventilation in the mills, to fence machinery, to shorten the hours of labor for women and children; and the law and scientific progress have improved the sanitary conditions not only of the mills but the towns.

It should be emphasized perhaps, in conclusion, that the pres-

${ }^{61}$ It may be noted that there are many indications that women played their part not only in the early "turn-outs" but in the later and better organized strikes. See, e.g., Condy Raguet, Journal of Political Economy, Vol. I, p. 73. for note of a "turn-out" in 1829, and Mrs. Robinson, op. cit., for a Lowell "turn-out" in the thirties against a reduction of wages. The Boston Evening Transcript, of March 25, 1836, contains the following interesting paragraph: "The factory girls of Amesbury have had a flare-up, and turned out. . . . The girls were told they must tend two looms in the future, by which they would weave double the number of yards that they now weave on one loom, and this without any advance of wages. .... They proceeded to the Baptist vestry, chose officers, and passed resolutions, pledging themselves under a forfeiture of five dollars, that they would not go back without all. The agent, finding them determined to persevere, sent a written notice that they might come back!" Mention has already been made of an early strike against the first reduction of wages in Lowell; and in $1836-37$, in Dover, N. H., a proposed reduction of wages caused a "turn-out" in which all of the women seem to have participated. This strike lasted but three or four days during which the girls "placarded the fence of the mill-yard and door of the office with rhymes composed for the occasion" (McNeill, op. cit., p. 89; see also pp. 103, I04). These were of course only sporadic associations and there seems to be no evidence of an attempt to build up a permanent organization. The Female Labor Reform Asso- 
ent paper is a study in industrial history and that no attempt has been made to discuss the economic or social conditions of the cotton-mill towns of today. It is unquestionably true that the Lowell, for example, of the twentieth century impresses the visitor more unfavorably than did the Lowell of fifty or seventy years ago, but the changes are due primarily to one fact, the substitution of immigrant operatives for the educated New England women who first filled the mills. The educated woman has passed from mechanical occupations into various professional employments, and the number of these which have been opened to her in the last half-century is the measure of the new opportunity that the world has offered her.

\section{NOTE A}

RULES AND REGULATIONS FOR EARLY CORPORATION BOARDING-HOUSES

I. Poignaud and Plant Boarding-House at Lancaster (Decade i820-30) Rules and Regulations to be attended to and followed by the Young Persons who come to Board in this House: ${ }^{1}$

Rule first: Each one to enter the house without unnecessary noise or confusion, and hang up their bonnet, shawl, coat, etc., etc., in the entry.

Rule second: Each one to have their place at table during meals, the two which have worked the greatest length of time in the Factory to sit on each side of the head of the table, so that all new hands will of course take their seats lower down, according to the length of time they have been here.

ciation of Lowell, some of whose early factory tracts are preserved in the Boston Public Library, is the nearest approach to anything that might be called a "movement." This women's organization presented a written address at the first Industrial Congress of the United States (New York, I845). The most interesting of the later strikes in which women played a part was that of the Fall River weavers in 1875 . In 1874 the men weavers had met without the women and voted to accept a marked reduction of wages; but the women at a meeting of their own, at which no men except reporters were admitted, decided to strike, beginning with three mills only, so that some could go on working and support those striking. This was a very bold step, for they were acting in opposition to the decision of the men weavers and they did not know whether they would receive any support from the men. Their action, however, was indorsed by the men's committee and the great strike of 1875 began.

${ }^{1}$ From the collection of Poignaud and Plant papers in the Lancaster Town Library. There is no date on this paper, but it clearly belongs to the decade 1820-30. 
Rule third: It is expected that order and good manners will be observed at table during meals-and at all other times either upstairs or down.

Rule fourth: There is no unnecessary dirt to be brought into the house by the Boarders, such as apple cores or peels, or nut shells, etc.

Rule fifth: Each boarder is to take her turn in making the bed and sweeping the chamber in which she sleeps.

Rule sixth: Those who have worked the longest in the Factory are to sleep in the North Chamber and the new hands will sleep in the South Chamber.

Rule seventh: As a lamp will be lighted every night upstairs and placed in a lanthorn, it is expected that no boarder will take a light into the chambers.

Rule eighth: The doors will be closed at ten o'clock at night, winter and summer, at which time each boarder will be expected to retire to bed.

Rule ninth: Sunday being appointed by our Creator as a Day of Rest and Religious Exercises, it is expected that all the boarders will have sufficient discretion as to pay suitable attention to the day, and if they cannot attend to some place of Public Worship they will keep within doors and improve their time in reading, writing, and in other valuable and harmless employment.

\section{The Lowell Manufacturing Company (Decade i830-490)}

The Overseers are to be punctually in their Rooms at the starting of the Mill, and not to be absent unnecessarily during working hours. They are to see that all those employed in their Rooms are in their places in due season; they may grant leave of absence to those employed under them, when there are spare hands in the Room to supply their places; otherwise they are not to grant leave of absence, except in cases of absolute necessity.

All persons in the employ of the Lowell Manufacturing Company are required to observe the Regulations of the overseer of the Room where they are employed; they are not to be absent from work without his consent, except in cases of sickness, and then they are to send him word of the cause of their absence.

They are to board in one of the Boarding-Houses belonging to the Company, and to conform to the regulations of the House where they board; they are to give information at the Counting-Room, of the place where they board, when they begin; and also give notice whenever they change their boarding-place.

The Company will not employ any one who is habitually absent from public worship on the Sabbath.

${ }^{2}$ From the Appendix to Seth Luther's Address to the Working Men of New England (pamphlet, 3 d ed., Philadelphia, 1836 ). 
It is considered a part of the engagement that each person remains twelve months if required; and all persons intending to leave the employment of the Company are to give two weeks' notice of their intention to their Overseer, and their engagement is not considered as fulfilled unless they comply with this Regulation.

The Pay Roll will be made up to the last Saturday of every month, and the payment made to the Carpet Mill the following Saturday, and the Cotton Mill the succeeding Tuesday, when every person will be expected to pay their board.

The Company will not continue to employ any person who shall be wanting in proper respect to the females employed by the company, or who shall smoke within the company's premises, or be guilty of inebriety, or other improper conduct.

The Tenants of the Boarding-Houses are not to board or permit any part of their Houses to be occupied by any person, except those in the employ of the company.

They will be considered answerable for any improper conduct in their Houses, and are not to permit their Boarders to have company at unseasonable hours.

The doors must be closed at Io o'clock in the evening, and no person admitted after that time without some reasonable excuse.

The keepers of the Boarding-Houses must give an account of the number, names and employment of the Boarders when required, and report the names of such as are guilty of any improper conduct.

The Buildings, and yards about them, must be kept clean and in good order, and if they are injured otherwise than from ordinary use, all necessary repairs will be made and charged to the occupant.

It is desirable that the families of those who live in the Houses, as well as the Boarders, who have not had the Kine Pox, should be vaccinated; which will be done at the expense of the Company for such as wish it.

Some suitable chamber in the House must be reserved, and appropriated for the use of the sick, so that others may not be under the necessity of sleeping in the same room.

No one will be continued as a Tenant who shall suffer ashes to be put into any place other than the place made to receive them, or shall, by any carelessness in the use of fire, or lights, endanger the Company's property.

These regulations are considered a part of the contract with the persons entering into the employment of the Lowell Manufacturing Company.

\section{Edith Аввотт}

Chicago School of Civics and Philanthropy 